\title{
Aorta Remodelling Associated with Calcitonin Gene Related Peptide Concentration in Rats with Arterial Hypertension
}

\author{
Petra Kochová1,2, Zbyněk Tonar ${ }^{1,2,3}$, Vít M. Matějka², Jitka Švíglerová4 ${ }^{4}$, Milan Šteng1 ${ }^{4}$, \\ Jitka Kuncová ${ }^{4}$ \\ ${ }^{1}$ Department of Mechanics, Faculty of Applied Sciences, University of West Bohemia in Pilsen, \\ Czech Republic \\ ${ }^{2}$ Department of Histology and Embryology, Faculty of Medicine in Pilsen, Charles University in Prague, \\ Pilsen, Czech Republic \\ ${ }^{3}$ Laboratory for Atherosclerosis Research, Institute for Clinical and Experimental Medicine, Prague, \\ Czech Republic \\ ${ }^{4}$ Department of Physiology, Faculty of Medicine in Pilsen, Charles University in Prague, Pilsen, \\ Czech Republic \\ Received December 23, 2008 \\ Accepted May 18, 2009
}

\begin{abstract}
Long-term hypertension in arteries leads to remodelling of the arterial wall. We focused on morphological changes in the wall of the subrenal aorta in rats suffering from arterial hypertension and chronic renal failure induced by $5 / 6$ nephrectomy (NX). We quantified the area of the profile of the arterial lumen, the volume fraction of elastin and smooth muscle cells (SMC) in the tunica media, the thickness of the intima-media, the length density of elastin lamellae, the lamellar unit thickness and the lamellar number. Calcitonin gene related peptide (CGRP) was assayed in extracts of aortic tissue and in plasma. Ten days after the subtotal nephrectomy, the structure of the aorta of NX rats did not differ compared to control animals. Pronounced structural changes were observed ten weeks after 5/6 nephrectomy. The area of the lumen profile, the elastin volume fraction and the elastin lamellar number in the tunica media were all significantly higher $(p<0.001)$ in NX than in control animals. The SMC volume fraction in the tunica media and the lamellar unit thickness were lower $(p<0.001)$ in NX than in control animals. The CGRP concentration was significantly higher $(p<0.05)$ in the aortas and in plasma of NX rats both ten days and ten weeks after operation when compared to sham operated animals. Our study demonstrated intensive remodelling of the aorta over the course of 10 weeks following induction of chronic renal failure. This was associated with a long-term increase in calcitonin gene related peptide concentrations in the plasma and aorta.
\end{abstract}

Histology, stereology, chronic renal failure, nephrectomy, quantitative microscopy

The basic structure of blood vessel wall consists of three distinct concentric layers: the tunica intima, media and adventitia. The tunica intima is the innermost layer consisting of the endothelium and subendothelial connective tissue. The tunica media consists of smooth muscle tissue, elastin and collagen fibres. In elastic arteries, the media is composed of layers of circumferentially or helically oriented smooth muscle cells (SMC) (Zervoudaki and Toutouzas 2003). Each layer is surrounded by densely distributed elastin fibres oriented along the long axis of the smooth muscle cells. In the inner section of this dense elastin network there is an interstitial matrix that consists of collagen (types I, III and IV) and of basement membrane, circumferentially oriented, that surrounds the cells and ensures their continuity and integrity. The tunica adventitia is the outer cladding of the vessel, consisting of connective tissue, fibroblasts, a few smooth muscle cells, and a multitude of nerve fibres and capillaries. Smooth muscle cells comprise most of the media of arteries. Contraction of SMC reduces the calibre of the vessel lumen, which reduces blood flow through the vessel and raises the pressure on the proximal side. SMC can also alter the rigidity of the wall, without causing constriction, and this affects the distensibility of the wall and propagation

Address for correspondence:

Petra Kochová, Ph.D.

Department of Mechanics, Faculty of Applied Sciences

University of West Bohemia

Univerzitní 22, 30614 Pilsen, Czech Republic
Phone: +420377632364

Fax: +420377632302

E-mail: kochovap@kme.zcu.cz

http://www.vfu.cz/acta-vet/actavet.htm 
of the pulse. The SMC synthesize and secrete elastin, collagen and other extracellular components of the media, all of which are directly linked to mechanical properties of the vessels (Plante 2002).

Hypertension is a common condition producing progressive structural changes in both elastic and muscular arteries. The arterial wall increases in diameter and the intima media becomes thicker (Bund and Lee 2003; Intengan and Schiffrin 2001; Sasamura et al. 2005). In essential hypertension, the resistive arteries exhibit a reduced lumen diameter, increased ratio of media thickness/lumen diameter and unchanged cross-sectional area of the media. Mild to moderate hypertension leads to a rearrangement of the vascular structure leaving the cross-sectional area of the arterial wall unchanged, reducing the lumen area. Severe hypertension or certain types of secondary hypertension involve hypertrophy of the vascular wall which results in an increase in the arterial wall cross-sectional area together with a decrease in lumen diameter. Due to this remodelling, the wall stress is elevated, and this in turn is followed by an increase in elastin and collagen synthesis (Deyl et al. 1987; Durmowicz and Stenmark 1999; Spector et al. 1978). Increased synthesis of structural proteins in hypertension is associated also with changes in other extracellular matrix components such as proteoglycans, other glycoproteins and the adhesive protein fibronectin (Plante 2002).

Remodelling involves the changes in the lumen that can be hypertrophic, eutrophic or hypotrophic. In hypertrophic remodelling, the cross-sectional area is increased. In eutrophic remodelling, it remains the same, whereas it is decreased in hypotrophic remodelling (Mulvany 1999; Bund and Lee 2003). These three groups can be further classified in terms of inward and outward remodelling. During remodelling, mechanical or chemical signals from the cells are detected, thus stimulating cellular response such as synthesis, activation or release of substances that influence cellular or non-cellular processes (Zervoudaki and Toutouzas 2003). In the media of the hypertensive pulmonary vessel wall, substances produced by endothelial cells influenced contractile, growth and synthetic properties of smooth muscle cells (Stenmark et al. 1988). In this paper, at four days of simulated high altitude the smooth muscle cells were phenotypically modulated so they proliferated and produced more collagen and elastin. However, the onset and time-related nature of these changes have not been described to date in hypertensive rats.

Hypertensive vascular remodelling contributes to increased peripheral resistance, impacting both the development of and complications associated with hypertension. The regulation of blood pressure involves two important systems: the sympathetic nervous system and the renin-angiotensin-aldosterone system (for details, see Samani and Swales 1991). Most antihypertensive drugs are vasodilators modulating the natural hormonal or neuronal mechanisms responsible for blood pressure regulation, while others act directly on the blood vessel wall. Less commonly, antihypertensive action is achieved by reducing cardiac output. Direct arterial dilation is responsible for long-term reductions in blood pressure. Vasodilation may result from reduced $\mathrm{Ca}^{2+}$ entry into the smooth muscle cells of the vessel wall and from synthesis of vasodilatory prostaglandins. Calcitonin gene related peptide (CGRP) is released from virtually all sensory perivascular nerves and is the most potent endogenous vasodilator currently known, acting as a compensatory vasodilator to partially counteract the increased blood pressure (Ghatta and Nimmagadda 2004; Lundberg et al. 1991; Wimalawansa 1996). Although CGRP is primarily produced in nervous tissue, its receptors are expressed throughout the body (Rorabaugh et al. 2001).

The aim of our study was to quantify the possible remodelling of arterial walls (area of the arterial lumen; volume fraction of smooth muscle cells and elastin in the tunica media; lamellar number, length density and lamellar unit thickness of elastin fibrils; and the intima media thickness) to determine the type, onset and progress of remodelling. The structural indicators were studied over 10 days and 10 weeks following the induction of hypertension 
and chronic renal failure (CRF). All results were compared with those obtained in control animals. A secondary aim of the study was to measure the levels of CGRP in the plasma and aorta 10 days and 10 weeks after subtotal nephrectomy.

\section{Materials and Methods}

The animal preparation and surgical induction of CRF has been published earlier (Kochová et al. 2008). In brief, 24 male 4-month-old Wistar rats (VELAZ, Prague, Czech Republic) kept on standard laboratory chow were randomized into two groups: the subtotal nephrectomy $(N X, n=12)$ and sham (control, $n=12)$ operation. The blood pressure was measured at the beginning of the experiment and every two weeks thereafter using tail plethysmography (Kent Scientific Co., CT, USA). The experiments were conducted in accordance with the European Directive for the Protection of Vertebrate Animals Used for Experimental and Other Scientific Purposes (86/609/EU), the relevant Guidelines of the Czech Ministry of Agriculture for scientific experimentation in animals and were approved by the University Committee for Experiments on Laboratory Animals.

The animals were anaesthetized and killed by decapitation ten days (six nephrectomized and six shamoperated rats) or ten weeks (six nephrectomized and six sham-operated rats) following subtotal nephrectomy or sham operation. The entire descending aorta was dissected and weighed. A $2 \mathrm{~mm}$ segment of the subrenal aorta underwent histological processing as described in study Kochova et al. (2008). Each sample was cut into 72 serial sections perpendicular to the long axis of the aorta with a thickness of $5 \mu \mathrm{m}$. The green trichrome and Verhoeff's haematoxylin was used for staining as shown in (Plate ÍII, Fig. 1).

Quantitative microscopy

Seven quantitative indicators were used to determine the possible arterial wall remodelling: cross-sectional area of the arterial lumen, intima media thickness, volume fraction of SMC in the tunica media, volume fraction of elastin in the tunica media, lamellar number of elastin fibrils, lamellar unit thickness of elastin fibrils, and length density of elastin lamellae. These indicators were estimated as described before in Kochova et al. (2008). We used standard stereological methods such as Cavalieri method, Buffon's needle method, or linear morphometry (Mouton 2001; Russ and Dehoff 1999). Twelve equidistant sections were selected using systematic uniform random sampling.

We assessed the area of the profile of the arterial lumen and the area of profiles of elastin and smooth muscle in each tissue section using a method based on counting the intersections between point grid test probe and profiles of the object of interest. The resultant area was further multiplied by distance between two subsequent selected sections according to Cavalieri principle to assess the volume of elastin and smooth muscle in reference space (Gundersen and Jensen 1987). The volume fraction of elastin $\mathrm{V}_{\mathrm{V}}$ (elastin, media) and volume fraction of SMC $\mathrm{V}_{\mathrm{V}}$ (SMC, media) within the tunica media were calculated by dividing the volume of the relevant structure by the reference volume of the tunica media. IMT indicates intima media thickness in the direction of the radial axis, and the lamellar number LN represents the number of elastin lamellae of the tunica media counted in the direction of the radial axis. The lamellar unit thickness LUT represents the mean interlamellar distance between adjacent profiles of the elastin lamellae and it was defined as the intima media thickness divided by the lamellar number. The 2-D length density of elastin lamellae $\mathrm{L}_{\mathrm{A}}$ (elastin, media) was assessed using a method based on counting the intersections of the elastin fibres and membranes using a network of circular arcs that was randomly superposed on the micrographs.

Biochemical Assays

Creatinine and urea concentrations in the plasma were measured using routine photometric methods (Olympus AU 2700, Japan). CGRP was extracted from pulverized aortas by boiling in 10 volumes of $0.1 \mathrm{~mol} / 1 \mathrm{HCl}$ containing $100 \mathrm{mmol} / 1 \mathrm{EDTA}$ and $0.01 \% \mathrm{Na}_{2} \mathrm{~S}_{2} \mathrm{O}_{5}$, rapid cooling on ice, homogenization, and subsequent centrifugation. The supernatants were stored at $-70^{\circ} \mathrm{C}$ until radioimmunoassays (RIA) were used to measure CGRP concentrations. CGRP levels were assayed in tissue extracts and plasma by RIA using commercial kits (Phoenix Pharmaceuticals, CA, USA).

Statistical Analysis

Statistica Base 7.1 (StatSoft, Inc., Tulsa, OK, USA) was used for data processing. Normality of the data was tested with the Shapiro-Wilkins W test. The Levene and Brown-Forsythe tests were used to assess variance homogeneity. The differences between the NX and sham operated groups were evaluated using unpaired Student's $t$-test. The results were considered significantly different when $p<0.05$.

\section{Results}

The values of body weight, weight of aorta, urea and creatinine concentration in plasma, and systolic and diastolic blood pressure of rats 10 days and 10 weeks after the subtotal nephrectomy or sham operation are summarized in Table 1.

Ten days after the operation (Fig. 2), the value of elastin length density was higher for 
Table 1. General indicators measured in rats 10 days (10D) and 10 weeks (10W) after the sham operation (SHAM) or 5/6 nephrectomy (NX). Data are means $\pm \mathrm{SD}$. * indicates $p<0.05$ ( $n=6$ per group).

\begin{tabular}{|l|c|c|c|c|}
\hline & SHAM 10D & SHAM 10W & NX 10D & NX 10W \\
\hline Body weight (g) & $429 \pm 9$ & $453 \pm 10$ & $364 \pm 12^{*}$ & $403 \pm 15^{*}$ \\
\hline Aorta (mg) & $108 \pm 11$ & $101 \pm 4$ & $105 \pm 11$ & $132 \pm 6$ \\
\hline Subrenal aorta (mg) & $20 \pm 4$ & $33 \pm 2$ & $22 \pm 5$ & $39 \pm 2^{*}$ \\
\hline Urea (mmol/1) & $7.1 \pm 0.2$ & $7.1 \pm 0.2$ & $26.9 \pm 2^{*}$ & $24.7 \pm 3.1^{*}$ \\
\hline Creatinine (mm Hg) & $45.2 \pm 1.6$ & $44.7 \pm 0.65$ & $108 \pm 10^{*}$ & $127.3 \pm 17^{*}$ \\
\hline Systolic pressure (mm Hg) & $140 \pm 8$ & $138 \pm 9$ & $145 \pm 9$ & $202 \pm 7^{*}$ \\
\hline Diastolic pressure (mm Hg) & $92 \pm 7$ & $102 \pm 4$ & $89 \pm 5$ & $133 \pm 8^{*}$ \\
\hline
\end{tabular}

NX rats than for sham operated animals $(p=0.006)$. Intima media thickness, volume fraction of elastin $\mathrm{V}_{\mathrm{V}}$ (elastin, media), volume fraction of $\mathrm{SMC} \mathrm{V}_{\mathrm{V}}(\mathrm{SMC}$, media), lamellar unit thickness and lamellar number did not differ between NX and sham operated groups. The cross-sectional area of the arterial lumen 10 days after operation was $7.3 \pm 2.7$ in the sham operated and $8.9 \pm 1.8 \mathrm{~mm}^{2}$ in the NX animals, respectively.

Ten weeks after the operation (Fig. 3), volume fraction $\mathrm{V}_{\mathrm{V}}$ (elastin, media) was higher in NX rats compared to sham operated animals $(p<0.001)$. By contrast, SMC volume fractions $\mathrm{V}_{\mathrm{V}}$ (SMC, media) were lower in NX animals than in sham operated rats $(p<$ $0.001)$. No significant differences were found in the elastin length density and intima media thickness between the two groups of rats. Lamellar unit thickness was significantly lower $(p<0.001)$ and lamellar number was significantly higher $(p<0.001)$ in NX than in sham

Table 2. CGRP concentrations in the aorta and plasma of rats 10 days (10D) and 10 weeks (10W) after the sham operation (SHAM) or 5/6 nephrectomy (NX). Data are means $\pm \mathrm{SD}$. $*$ indicates $p<0.05$ ( $n=6$ per group).

\begin{tabular}{|l|c|c|}
\hline CGRP concentration & \multicolumn{1}{|c|}{ SHAM } & \multicolumn{1}{c|}{ NX } \\
\hline Aorta 10D $(\mathrm{ng} / \mathrm{g})$ & $1.49 \pm 0.21$ & $2.89 \pm 0.39^{*}$ \\
\hline Aorta 10W $(\mathrm{ng} / \mathrm{g})$ & $1.87 \pm 0.47$ & $3.1 \pm 0.75^{*}$ \\
\hline Plasma 10D $(\mathrm{pg} / \mathrm{ml})$ & $102.9 \pm 13.7$ & $149.5 \pm 11.1^{*}$ \\
\hline Plasma 10W $(\mathrm{pg} / \mathrm{ml})$ & $86.2 \pm 14.0$ & $130.2 \pm 10.8^{*}$ \\
\hline
\end{tabular}
of the arterial lumen 10 weeks after operation was $7.3 \pm 2.7$ in the control and $11.8 \pm 3.8 \mathrm{~mm}^{2}$ in the NX animals, respectively.

The mean CGRP level was significantly higher in the aortas of NX rats both 10 days and 10 weeks after operation as compared with sham operated animals. Similarly, the mean concentration of CGRP was significantly higher in the plasma of NX rats 10 days as well as 10 weeks after 5/6 nephrectomy compared to the sham operated rats, as shown in Table 2.

\section{Discussion}

The detailed histomorphometric analysis suggested that 10 days as well as 10 weeks following the hypertension induced by $5 / 6$ nephrectomy caused an outward hypertrophy of the aortas of subtotally nephrectomized rats, as evidenced by the increased weight of the vessel that was not accompanied by an increased vessel wall thickness.

Structural remodelling of the wall of the subrenal aorta in rats with induced hypertension developed over time - 10 days after the operation, most of the morphometric indicators were the same in NX as in control rats, except for an increased length density of elastin in NX rats compared to control animals. During the 10 weeks following the operation, much more structural indicators changed rapidly, namely the values of volume fraction of SMC as well as elastin, lamellar number of elastin and lamellar thickness of elastin. At the same time, the hypertrophy that became obvious 10 weeks after the operation seemed to be disproportionate to the increased fraction of elastin and the decreased relative proportion of SMC. In addition, the increase in relative volume of elastin alongside an increased lamellar 

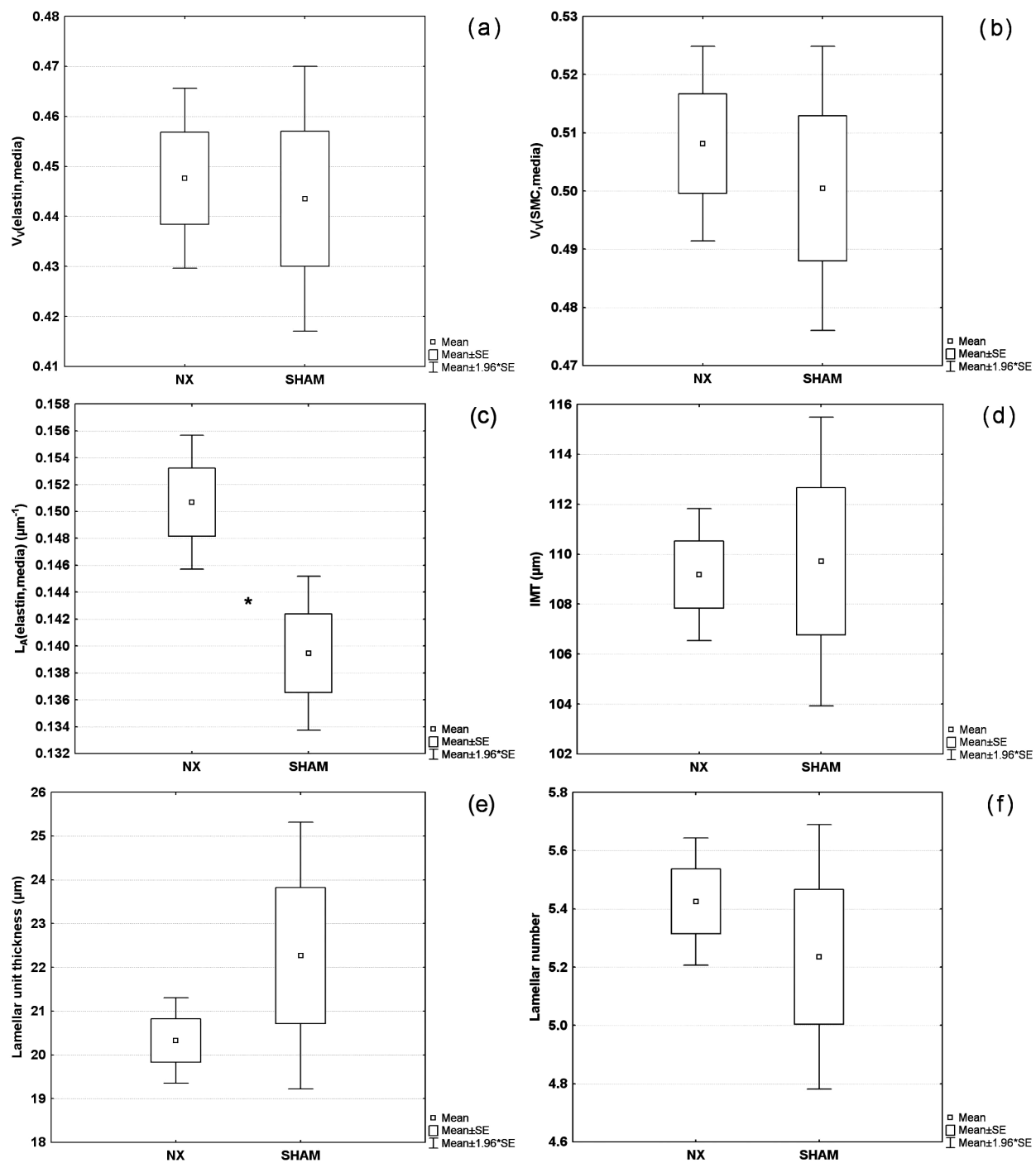

Fig. 2. Morphometric indicators of the wall of subrenal aortas of rats subjected to $5 / 6$ nephrectomy (NX) or sham operations (SHAM) 10 days following operation. We found no significant differences in the values of the volume fraction of elastin in the tunica media $\left(\mathrm{V}_{\mathrm{V}}\right.$ (elastin,media)), volume fraction of smooth muscle cells in the tunica media $\left(\mathrm{V}_{\mathrm{V}}(\mathrm{SMC}\right.$, media)), thickness of the intima media (IMT), lamellar unit thickness of elastin fibrils and lamellar number of elastin fibrils $(\mathrm{a}, \mathrm{b}, \mathrm{d}, \mathrm{e}, \mathrm{f})$. The length density of elastin lamellae in media ( $\mathrm{L}_{\mathrm{A}}($ elastin, media), c) was slightly higher for NX rats in comparison to control animals. * indicates $p<0.05$.

number and without any significant change in the cross-sectional length density of the elastin fibres suggested an absolute increase in the elastin content. These changes lead to an increase of the Young's modulus in the region of large deformations whereas they had no effect on the Young's modulus in the region of small deformations when the uniaxial tensile test was applied. Moreover, the ultimate strength before the tissue rupture was significantly 

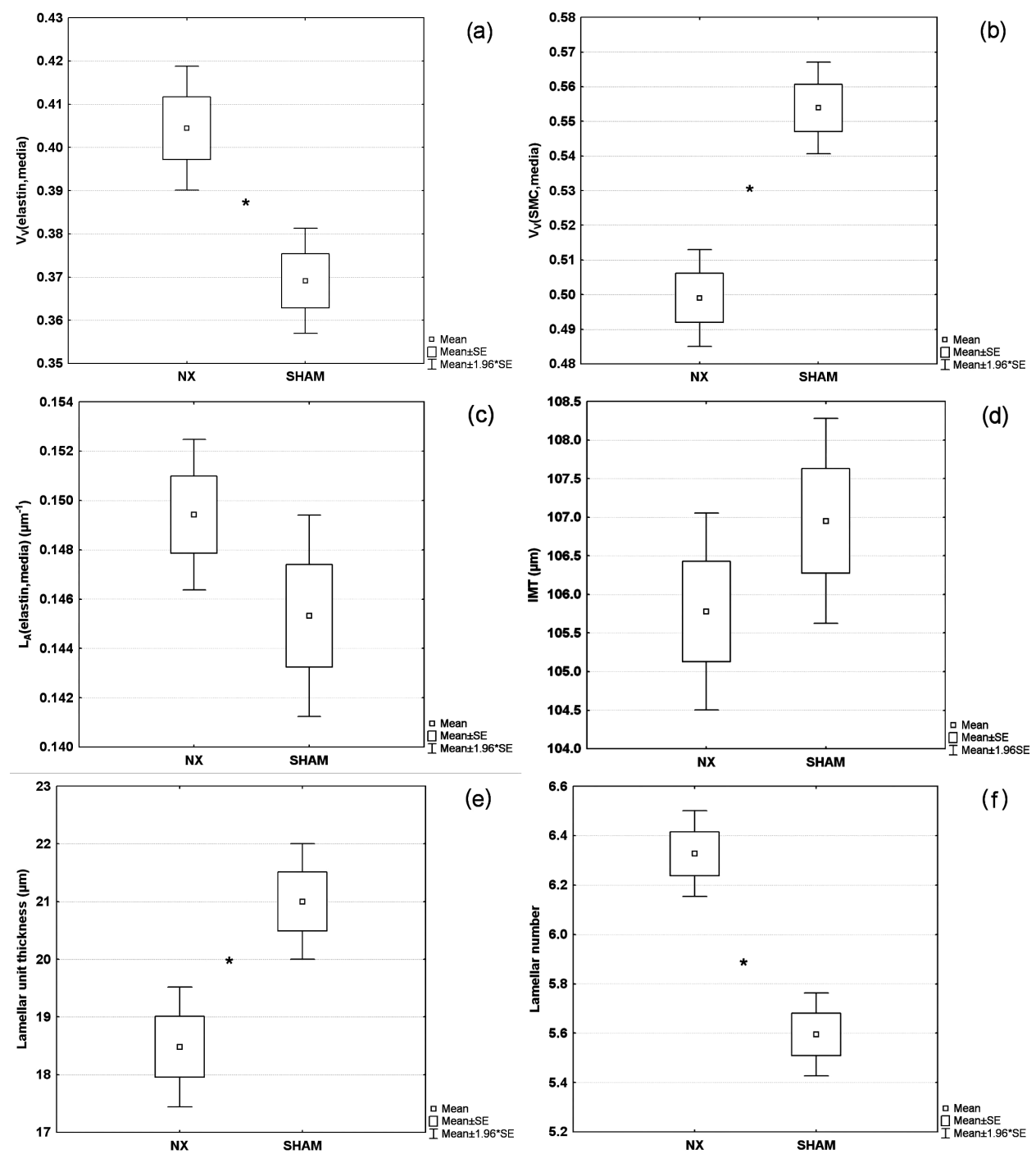

Fig. 3. Morphometric indicators of the wall of subrenal aorta of rats subjected to $5 / 6$ nephrectomy (NX) or sham operation (SHAM) 10 weeks following the operation. The volume fraction of elastin in the tunica media $\left(\mathrm{V}_{\mathrm{V}}\right.$ (elastin, media)) and the lamellar number of elastin fibrils were significantly higher in NX rats compared to sham operated rats $(\mathrm{a}, \mathrm{f})$. The volume fraction of smooth muscle cells in the tunica media $\left(\mathrm{V}_{\mathrm{Y}}(\mathrm{SMC}, \mathrm{media})\right)$ and the lamellar unit thickness of elastin fibrils were significantly lower in NX rats (b, e). No differences in the length density of elastin lamellae in the media ( $\mathrm{L}_{\mathrm{A}}$ (elastin, media)), and in thickness of the intima media were identified (c, d). * indicates $p<0.05$.

smaller for tissue with higher content of elastin (for detailed biomechanical analysis see Kochova et al. 2008). The levels of CGRP in the plasma and aortas were significantly higher as soon as 10 days after the induction of hypertension and CRF. They remained elevated until the end of experiment. In addition to its immediate powerful vasodilatory effect, CGRP also inhibits the proliferation of vascular smooth muscle cells. This is an 
effect that could be beneficial in the development of atherosclerotic complications of hypertension that are associated with abnormal arterial smooth muscle proliferation (Wimalawansa 1996).

In conclusion, our study demonstrated a significant remodelling of the aorta in the course of 10 days and also as much as 10 weeks following the induction of hypertension and CRF associated with a long-term increase in CGRP levels in the plasma and aorta. This remodelling was quantified using seven structural indicators: cross-sectional area of the arterial lumen; volume fraction of smooth muscle cells and elastin in the tunica media; lamellar number, length density and lamellar unit thickness of elastin fibrils; and thickness of the intima media. We found that the remodelling of the aortic wall induced by subtotal nephrectomy in rats can be understood in terms of outward hypertrophy combined with an increase in the cross-sectional area.

The quantitative histomorphometric indicators used in our research for the first time provide evidence that precise analyses of vessel wall remodelling can be used in studies dealing with different types of vessels in various models of vascular disease. We believe that these techniques will help us to define the extent of pathological change in vessel walls.

\section{Remodelace aorty je u potkanů s arteriální hypertenzí asociovaná se zvýšenými hodnotami peptidu odvozeného od genu pro kalcitonin}

Déletrvající hypertenze vede k remodelaci tepenné stěny. Cílem naší práce bylo popsat morfologické změny ve stěně subrenální aorty u potkanů s arteriální hypertenzí a chronickým renálním selháním indukovaným chirurgickým odstraněním 5/6 ledvinného parenchymu. Kvantifikovali jsme plochu prŕíného prưřezu průsvitem tepny, objemový podíl elastinu a hladkých svalových buněk v tunica media, tloušt'ku tunica intima et media, délkovou hustotu profilů elastinových lamel, sílu a počet lamelárních jednotek tunica media. V krevní plazmě a $\mathrm{v}$ extraktu z aortální tkáně byla stanovena hladina peptidu odvozeného od genu pro kalcitonin (CGRP). Deset dnů po subtotální nefrektomii se struktura aorty výrazně nelišila ve srovnání s kontrolními zvířaty bez nefrektomie. Deset týdnů po nefrektomii byly již prítomny výrazné změny $\mathrm{v}$ morfologii aorty: plocha příčného průřrezu průsvitem, objemový podíl elastinu a počet elastinových lamel v medii byl signifikantně vyšší u nefrektomovaných nežli u kontrolních zvířat. Objemový podíl hladkých svalových buněk a tloušt'ka lamelární jednotky byly signifikantně nižší u nefrektomovaných nežli u kontrolních zvířat. Hladina CGRP byla ve srovnání s kontrolami vyšší ve stěně aorty i v krevní plazmě nefrektomovaných zvírat jak po deseti dnech, tak po deseti týdnech od nefrektomie. Prokázali jsme tak význačnou remodelaci aorty př́ítomnou nejpozději deset týdnů po indukci chronického renálního selhání a hypertenze. Remodelace byla asociována se zvýšenými hodnotami tkáňového i cirkulujícího CGRP.

\section{Acknowledgement}

This work was supported by the Ministry of Education, Youth and Sports of the Czech Republic under Projects No. MŠM4977751303, MŠM0021620819, 1M6798582302, and by the Czech Science Foundation under Project GAČR 106/09/0734.

\section{References}

Bund SJ, Lee RMKW 2003: Arterial structural changes in hypertension: A considerations of methodology, terminology and functional consequence. J Vasc Res 40: 547-557

Deyl Z, Jelínek J, Macek K, Chaldakov G, Vankov VN 1987: Collagen and elastin synthesis in aorta of spontaneously hypertensive rats. Blood Vessels 24: 313-320

Durmowicz AG, Stenmark KR 1999: Mechanism of structural remodeling in chronic pulmonary hypertension. Pediatr Rev 20: e91-e102

Ghatta S, Nimmagadda D 2004: Calcitonin gene-related peptide: Understanding its role. Indian J Pharmacol 36: 277-283

Gundersen HJG, Jensen EB 1987: The efficiency of systematic sampling in stereology and its prediction. J Microsc 147: 229-263 
Howard CV, Reed MG 1998: Unbiased Stereology: Three Dimensional Measurement in Microscopy. $1^{\text {st }}$ edn. Royal Microscopical Society and Springer-Verlag, New York, 246 p.

Integan HD, Schiffrin EL 2001: Vascular remodeling in hypertension. Roles of apoptosis, inflammation, and fibrosis. Hypertension 38: 581-587

Kochova P, Tonar Z, Matejka VM, Sviglerova J, Stengl M, Kuncova J 2008: Morphology and mechanical properties of the subrenal aorta in normotensive and hypertensive rats. Biomed Pap Med Fac Univ Palacky Olomouc Czech Repub. 152: 239-245

Lundberg JM, Franco-Cereceda A, Lacroix JS, Pernow J 1991: Release of vasoactive peptides from autonomic and sensory nerves. Blood Vessels 28: 27-34

Mouton PR 2001: Principles and Practices of Unbiased Stereology: An Introduction for Bioscientists. The Johns Hopkins University Press, Baltimore, 214 p.

Mulvany MJ 1999: Vascular remodeling of resistance vessels: can we define this? Cardiovasc Res 41: 9-13

Plante GE 2002: Vascular response to stress in health and disease. Metabolism 51: 25-30

Rorabaugh BR, Scofield MA, Smith DD, Jeffries WB, Abel PW 2001: Functional calcitonin gene-related peptide subtype 2 receptors in porcine coronary arteries are identified as calcitonin gene-related peptide subtype 1 receptors by redioligand binding and reverse transcription-polymerase chain reaction. J Pharmacol Exp Ther 299: 1086-1094

Russ JC, Dehoff RT 2001: Classical stereological measures. In: Russ JC, Dehoff RT (Ed): Practical Stereology. 2nd edn. Plenum Press, New York, pp. 44-54

Samani NJ, Swales JD 1991: Molecular biology of the vascular renin-angiotensin system. Blood Vessels 28: $210-216$

Sasamura H, Shimizu-Hirota R, Satura T 2005: Extracellular matrix remodeling in hypertension. Curr Hypertens Rev 1: $51-60$

Spector S, Ooshima A, Iwatsuki K, Fuller G, Cardinale G, Udenfriend S 1978: Increased vascular collagen biosynthesis by hypertension and reversal by antihypertensive drugs. Blood Vessels 15: 176-182

Stenmark KR, Orton EC, Reeves JT, Voelkel NF, Crouch EC, Parks WC, Mecham RP 1988: Vascular remodelling in neonatal pulmonary hypertension. Chest 93: 127S-133S

Wimalawansa SJ 1996: Calcitonin Gene-Related Peptide and Its Receptors: Molecular Genetics, Physiology, Pathophysiology, and Therapeutic Potentials. Endocr Rev 17: 533-585

Zervoudaki AI, Toutouzas PK 2003: Remodeling of resistance vessels in essential hypertension. HJC 44: 116-124 